\title{
The Meaning of Moses' Life: An Analytic and Comparative-Philosophical Perspective
}

\author{
JACO GERICKE (NORTH-WEST UNIVERSITY)
}

\begin{abstract}
Against the backdrop of the problem of the meaning of life as constructed in contemporary analytic philosophy of religion, this article asks the question of what the supposed meaning(s) of the biblical character of Moses' life were assumed to be. By comparing a variety of contemporary philosophical perspectives on life's meaning with what appears to be related nascent metaphysical presuppositions in the world(s) of the biblical text, the pros and cons of reading with an anachronistic philosophical-theological meta-language are clearly demonstrated. It is concluded that what Moses' life might have meant cannot be reduced either to a singular purpose or a unified teleology. Given the complex construction of his character's personal identity over time, the point of it all remains fragmented, plural and elusive.
\end{abstract}

KEYWORDS: Moses; meaning of life; analytic philosophy; comparative philosophy.

\section{A INTRODUCTION}

Once upon a time in the world of the text began one of the most significant lives in the HB. ${ }^{1}$ The man Moses' life might have been rather short and pointless were it not for a number of miracles and set-backs which enabled it to drag on for a full 120 years in the story's symbolic time-frame. Having first survived an attempted infanticide, the first four decades were spent in the Pharaoh's court without any mentionable incidents besides committing murder.

* Article submitted: 10/01/2017; peer-reviewed: 10/02/2017; accepted: 17/05/2017. Jaco Gericke, "The Meaning of Moses' Life: An Analytic and ComparativePhilosophical Perspective,” Old Testament Essays 30/2 (2017): 315-336, doi; http:// dx.doi.org/10.17159/2312-3621/2017/v30n2a8

1 The character of Moses has arguably been the subject of more biographical writings across religious traditions than any other biblical character, from ancient apocryphal sources to modern secular perspectives. See Yishai Chasidah, Encyclopaedia of Biblical Personalities: Anthologized from the Talmud, Midrash and Rabbinic Writings (Brooklyn: Shaar Press, 1994), 340-99; Cornelis Houtman, "Moses," DDD: 595-597. Classic modern examples outside biblical scholarship include Martin Buber, Moses: The Revelation and the Covenant (New York: Harper, 1958); Sigmund Freud, Moses and Monotheism (New York: Vintage, 1967), and Elie Wiesel, Messengers of God: Biblical Portraits \& Legends (New York: Random House, 1976), 174-201. 
Thereafter Moses' life took a turn for the stranger and at age 40 he fled to a new country where he married and wandered around the desert as a shepherd for another four decades. After a decisive encounter with the god YHWH and now 80 years old, Moses went back to Egypt. With signs and wonders he is said to have led his people into the desert where he is represented as mediating the divine laws at Sinai/Horeb. After the people fell into sin repeatedly, Moses continued on his life's journey which basically involved assorted stressful yet memorable incidents whilst wandering in the wasteland for roughly another four decades. At the symbolically significant age of 120, still full of life, Moses died without entering the Promised Land and reaching the destiny of his final journey. Here ends the life of Moses. ${ }^{2}$

In view of the above one may well ask what, if anything, was the meaning of Moses' life assumed to be. ${ }^{3}$ The question itself is asked in the popular modern existential sense thereof, that is, what was the point, albeit in philosophical terms. Also, by the concept of “Moses' life" in this context, is not meant the life of some historical person called Moses in the world behind the text, whether or not the individual by that name and as depicted in the various sources and traditions existed at all. ${ }^{4}$ Rather, the question concerns a selection of aspects of an epiphenomenal teleology implicit in the framework of the stories of the Pentateuch. ${ }^{5}$ Of course, the narratives themselves neither ask nor answer the question of the philosophical meaning of Moses' life in so many words, that is, overtly or directly. Yet the texts contain nascent metaphysical assumptions not unrelated to the matter. ${ }^{6}$

2 For other more recent but possibly less famous examples of biographical and related studies, see Joel Cohen, Moses: A Memoir (Mahwah, NJ: Paulist Press, 2003); Jonathan Kirsch, Moses: A Life (New York: Ballantine, 1998); Aaron Wildavsky, Moses as Political Leader (Jerusalem: Shalem Press, 2005).

3 This, of course, assuming problematically that life is the kind of thing that a) has meaning; and/or b) is something to which the property of meaningfulness is properly predicated without it being a category mistake. Cf. also in this regard Robert A. Sharpe, "In Praise of the Meaningless Life," PhN 25 (1999): 15. This contribution simply assumes meaningfulness as a working hypothesis to see what turns up.

4 For an example of a historical-critical approach to Moses' life also familiar to many biblical scholars, see John van Seters, The Life of Moses: The Yahwist as Historian in Exodus-Numbers (Louisville: John Knox Press, 1994). In comparative religion, see Jan Assmann, Moses the Egyptian: The Memory of Egypt in Western Monotheism (Cambridge: Harvard University Press, 2009).

5 What I recount of Moses' life is always concerned with the story-world in the text and questions of historicity are bracketed. For a justification of such a limitation in the context of OT theology, see Walter Brueggemann, Theology of the Old Testament: Testimony, Dispute, Advocacy (Minneapolis: Fortress Press, 1997), 58.

6 For more on the question of philosophical assumptions nascent in biblical narratives, see William J. Abraham, "The Epistemology of Jesus: An Initial 
Gericke, “The Meaning of Moses’ Life,” OTE 30/2 (2017): 315-336

\section{B ASSUMPTIONS, FALLACIES AND DISCLAIMERS}

An inquiry such as this into a supposed meaning(s) of Moses' life has the potential to give rise to misunderstanding as to what it intends.

First of all, it will be granted that the focus on Moses' individual life reflects a modern Western concern that goes back to the Greeks and their interest in bioi. Secondly, it is also true that the question of the meaning of Moses' life in literary and historical-critical perspectives thereon is not a philosophical one at all but is concerned with the ideological and theological agendas of the post-exilic redactions of the Pentateuch. ${ }^{7}$ A valid concern raised as a result of these seemingly incommensurable related domains of secondorder scholarly discourse is that the article asks a question that did not concern the biblical authors. Surely the latter were only interested in the story of Moses in terms of the Israelites or Jews as a people and the use of Moses to legitimate later belief revision within the associated scribal and communal traditions.

In response to such an objection it may be noted that collectively the authors and redactors of the Pentateuch left us with fragmented life-stories for the character Moses. Whether any individual writer or final redaction intended it or not, the form and content of the Pentateuch in the Hebrew Bible as we most often read it in the Masoretic versions, contain implicit assumptions related to philosophical matters in initial, final and intermediary allusions and assessments of Moses' life from Genesis to Deuteronomy. These can be compared to ideas encountered in one or more perspectives on the meaning of life as found in contemporary analytic philosophical classifications of the various viewpoints to the (modern existential) problem. This is not done for the sake of claiming a philosophy as being present in the text. Neither is the comparative view offered in order to justify or criticize textual or readerly ideologies.

Consequently, the seemingly anachronistic philosophical approach adopted in this study should not be equated with a kind of pre-critical philosophical reading that lacks historical consciousness or which is unfamiliar with literary-critical findings regarding the composition history and literarytheological purpose of the Moses' traditions. The comparative-philosophical view offered here only seeks to compliment mainstream forms of biblical criticism concerned with the same topic. As such it is neither in competition

Investigation," in Jesus and Philosophy, ed. Paul K. Moser (Cambridge: Cambridge University Press, 2009), 149-158.

7 For some examples of the approach taken in mainstream literary-critical discussion, see Brian Britt, Rewriting Moses: The Narrative Eclipse of the Text, JSOTSup 402, GCT 14 (London: T \& T Clark, 2004), and Mark McEntire, Struggling with God: An Introduction to the Pentateuch (Macon, GA: Mercer University Press, 2008). 
with nor in the same genre of commentary as the more familiar literary, historical, social-scientific and theological approaches to the life of Moses.

\section{AN ANALYTIC AND COMPARATIVE PHILOSOPHICAL PERSPECTIVE}

The context constructed for the question of the meaning of Moses' life in the present article is to be located in the realm of comparative philosophy in general $^{8}$ and, in relation to Moses, in descriptive philosophy of religion ${ }^{9}$ in particular. In the discussion to follow an attempt will be made to provide a philosophical clarification of the meaning(s) of Moses' life from the perspective of certain possibly relevant philosophical concepts and categories. ${ }^{10}$ The purpose of such an approach is not to superimpose modern philosophical concepts, categories and concerns onto the traditions about the life of Moses in the world of the text. Quite the opposite: it is to show their inadequacy for descriptive purposes in doing comparative philosophy of religion in combination with HB interpretation.

At this point it is suffice to note that for most of the previous century, there was still a definite lack of interest in the question of the meaning of life,

8 For some representative and acknowledged edited volumes with general introductions of acceptable quality, see David Benatar, ed., Life, Death \& Meaning: Key Philosophical Readings on the Big Questions (Lanham, MD: Rowman \& Littlefield Publishers, 2004); Elmer D. Klemke and Stephen M. Cahn, eds., The Meaning of Life: A Reader, 3rd ed. (New York: Oxford University Press, 2007); Joseph Runzo and Nancy Martin, eds., The Meaning of Life in the World Religions (Oxford: Oneworld Publications, 2000); Joshua Seachris, ed., Exploring the Meaning of Life: An Anthology and Guide (Oxford: Wiley-Blackwell, 2012); For more brief historical overviews, see Terry Eagleton, The Meaning of Life: A Very Short Introduction (Oxford: Oxford University Press, 2007) and Dennis Ford, The Search for Meaning: A Short History (Berkeley: University of California Press, 2007).

9 In our own time the question of life's meaning is still hotly debated in analytic philosophy of religion. Some main related issues concern meaning in the contexts of atheism, immortality, ethics and value. For introductions to these topics, see John Cottingham, On the Meaning of Life (London: Routledge, 2003); Stewart Goetz, The Purpose of Life: A Theistic Perspective (New York: Continuum, 2012); Louise M. Antony, ed., Philosophers Without Gods: Meditations on Atheism and the Secular Life (Oxford: Oxford University Press, 2007); Michael Martin, Atheism, Morality, and Meaning (Amherst, NY: Prometheus Books, 2002); John Messerly, The Meaning of Life: Religious, Philosophical, Transhumanist and Scientific Approaches (Seattle: Darwin and Hume Publishers, 2012).

10 Besides philosophy of religion, ethics and axiology are also breeding grounds for debating the question of life's meaning. See e.g., Simon Blackburn, Being Good (New York: Oxford University Press, 2012); Irving Singer, Meaning in Life, Volume 1: The Creation of Value (Baltimore: John Hopkins University Press, 1996). 
at least within some circles of analytic philosophy ${ }^{11}$ and as a result of positivist reservations concerning the legitimacy of the query. ${ }^{12}$ Depending upon whom one asked, the question, "What is the meaning of life?" may have been considered to be either profound or nonsensical. In the latter case there was the logical problem of the question's inherent lack of clarity on the one hand and the worry about assumptions about what would have to be the case in order for life to have a meaning (as well as what that meaning might be). ${ }^{13}$ Over the last three decades, however, the situation has changed and in analytic philosophy two major areas of interest have arisen. First there is a concern with the meaning of the question itself.

It is surely not a question about the semantic meaning of the word "life," but what then is it a question about? Is it a question about human life? Is it a question about all biological life? Is it a question about all of existence? Is it asking for a comprehensive explanation of why the universe exists and of our place within it? And if so, is it asked with strong teleological assumptions at the fore, such that a purely efficient, mechanistic causal story would leave the inquirer unsatisfied? These latter questions with a global focus seem to track a request like, "What is it all about?"14

Given the initial vagueness, these questions partially clarify the question's meaning. They all pertain to the explanatory dimension wherein

11 Continental philosophy, by contrast, showed great interest in the question of meaning during the twentieth-century, as was evident in existentialist thought and its aftermath, cf. e.g., Jean-Paul Sartre, Existentialism is a Humanism, trans. by Philip Mairet (London: Methuen \& Co, 1948); Albert Camus, The Myth of Sisyphus (New York: Vintage Books, 1955); Other instances include parts of the writings of philosophers as diverse as Kierkegaard, Nietzsche and Heidegger.

12 See Thaddeus Metz, "The Meaning of Life," in The Stanford Encyclopedia of Philosophy (Summer 2007 ed.), ed. Edward N. Zalta, online: http://plato.stanford.edu /archives/sum2013/entries/life-meaning/; and Thaddeus Metz, Meaning in Life: An Analytic Study (Oxford: Oxford University Press, 2013).

13 Joshua Seachris, "The Meaning of Life, Analytic Perspectives," in Internet Encyclopedia of Philosophy, online: http://www.iep.utm.edu/mean-ana/. See classically onwards from William James, "What Makes a Life Significant?” in On Some of Life's Ideals (New York: Henry Holt and Company, 1900), 49-94; and especially Alfred-Jules Ayer, "The Claims of Philosophy," repr. in The Meaning of Life, ed. Elmer D. Klemke, 2nd ed. (New York: Oxford University Press, 2000), 21932.

14 Seachris, “Analytic Perspectives,” http://www.iep.utm.edu/mean-ana/. On normativity, see also Susan Wolf, Meaning in Life and Why It Matters (Princeton: Princeton University Press, 2010). 
a narrative explanation making sense of the world and one's life therein is sought. ${ }^{15}$

The second focus area in analytic philosophical approaches to the meaning of life is connected to the first and is concerned with necessary and sufficient conditions for a meaningful life, that is, with the normative dimension of the meaning-of-life question. ${ }^{16}$

When asking these, we are more concerned with the aim of securing a meaningful life. We wonder what we must, or should, or ought to order our lives around so as to render them meaningful. Meaningfulness, then, perhaps supervenes on a life properly ordered around the right stuff. Questions within this dimension include, "What is (are) the purpose(s) of life (my life)?" "What makes life valuable?" or "What makes life worthwhile and not irredeemably futile?"17

As can be seen here, the question of the meaning of life is thought to involve "a complex cluster of related yet distinct concerns with purpose, value, worth, significance, death and futility." 18 As such, the riddle is also to be distinguished from yet correlated with "concerns with rightness and wrongness, aesthetic requests about what is good and beautiful, and eudaimonistic interests in happiness."19

In the present article, the aim is not to determine the meaning of life absolutely in order to pronounce a metaphysical judgement on the life of Moses. Rather, the question is what, if anything, some parts of the narratives in the Pentateuch assumed regarding the meaning(s) of Moses' life. In other words, looking at various philosophical theories about life's meaning, can one comparatively locate textual perspectives on the life of Moses on the philosophical map to clarify the metaphysics nascent in the discourse?

\section{CONTEMPORARY PHILOSOPHICAL THEORIES AND THEIR DRAWBACKS IN THE CONTEXT OF THE HEBREW BIBLE}

In general, little descriptive philosophical research on biblical assumptions on the meaning of life currently exists. In biblical scholarship such philosophical

15 Seachris, “Analytic Perspectives,” http://www.iep.utm.edu/mean-ana/. It is generally accepted that humans seek a profound narrative through which to interpret their existence. See Joshua Seachris, "The Meaning of Life as Narrative: A New Proposal for Interpreting Philosophy’s 'Primary' Question,” Philo 12 (2009): 5-23; and "Death, Futility, and the Proleptic Power of Narrative Ending," RelS 47 (2011): 141-163. See also Jay Bernstien, "Grand Narratives," in Paul Ricoeur: Narrative and Interpretation, ed. David Wood (London: Routledge, 1991), 102-23.

16 See Seachris, “Analytic Perspectives,” http://www.iep.utm.edu/mean-ana/.

17 Seachris, “Analytic Perspectives,” http://www.iep.utm.edu/mean-ana/.

18 Seachris, “Analytic Perspectives,” http://www.iep.utm.edu/mean-ana/.

19 Seachris, “Analytic Perspectives,” http://www.iep.utm.edu/mean-ana/. 
excursions are rare, while in philosophy proper, one does not usually start the investigation with the ANE or the HB but instead commences with the problem as it appears in early Greek thought. ${ }^{20}$ This has been the case despite ample evidence of a similar concern in much of the pre- and non-Greek philosophical literature. ${ }^{21}$

In the Greek context itself, however, no single or coherent view on the matter ever existed. Much of western philosophy are footnotes to Plato and Aristotle's views, which may be classified as a metaphysical/epistemological (knowledge of the Form of the Good) and an ethical/axiological (happiness and well-being) take on the meaning of life respectively. ${ }^{22}$ In later Judaism and Christianity these ideas were combined and put within a theological context (knowledge of God and spiritual bliss). Yet any research done with historical consciousness must first determine whether the idea that these goals were also those taken for granted by the biblical narratives for Moses's own life might not be presumptuous (i.e., anachronistic).

Nowadays a variety of philosophical categories are employed to designate different views on the meaning of life. ${ }^{23}$ One of these is called "supernaturalism," which prima facie might be thought as being a "biblical” view on the matter.

Supernaturalist theories are views that meaning in life must be constituted by a certain relationship with a spiritual realm. If God or a soul does not exist, or if they exist but one fails to have the right relationship with them, then supernaturalism-or the Western version of it-entails that one's life is meaningless. ${ }^{24}$

If the above is taken as representative then technically the Mosaic narratives cannot be classified with the category of supernaturalism, simply because of the fact that the dichotomy between natural and supernatural is in some sense foreign to ancient Israelite metaphysics, which tended to lump the two realms together. ${ }^{25}$ Even if one did try to place the Mosaic traditions with this modern category, further problems arise due to specific anachronistic meta-

20 Jaco Gericke, The Hebrew Bible and Philosophy of Religion, RBL 70 (Atlanta: Society of Biblical Literature), 433-437.

21 Cf. parallels in Egyptian and Babylonian wisdom literature questioning the value of life.

22 See Metz, “Meaning of Life,” http://plato.stanford.edu/archives/sum2013/entries /life-meaning/.

23 Thaddeus Metz, "New Developments in the Meaning of Life,” PhC 2 (2007): 196217; Thaddeus Metz, "Recent Work on the Meaning of Life,” Ethics 112 (2002): 781814.

24 Metz, "Meaning of Life,” http://plato.stanford.edu/archives/sum2013/entries/lifemeaning/.

25 See Gericke, Hebrew Bible, 255. 
theistic assumptions. ${ }^{26}$ Consider, for example, the presumption of perfect-being theology within the supernatural category when a distinction is made between so-called “God-centred” and "soul-centred” views.

The former take some kind of connection with God (understood to be a spiritual person who is all-knowing, all-good, and all-powerful and who is the ground of the physical universe) to constitute meaning in life, even if one lacks a soul (construed as an immortal, spiritual substance). The latter deem having a soul and putting it into a certain state to be what makes life meaningful, even if God does not exist. ${ }^{27}$

The notions of maximal greatness of philosophical monotheism taken for granted here is absent from the more "primitive" theologies of many Mosaic traditions, such as texts where monolatry is the default form of theism and in characterisations of YHWH were the deity is not assumed to be omniscient, omnipotent and omnibenevolent in the modern sense of these concepts. ${ }^{28}$ Also the soul-centred view, either connected to or divorced from theism seems unthinkable in the world of the text in as much as humans were not assumed to be “immortal spiritual substances."29

In other words, imposing modern supernaturalist God-centred categories onto the world in the text would distort the metaphysics implicit in the otherwise theistic discourse. Hence the historical philosophy we are interested in is required to pay attention to the metaphysical presuppositions incidentally part of the story world in the text itself to discern alternative ways of conceptualisation. Only then can one ask comparatively-philosophically what meaning, if any, Moses' life as constructed in the discourse might have had in relation to modern categories.

\section{E METAPHYSICAL ASSUMPTIONS IN THE TEXTS}

As regards the inner-biblical perspectives adopted in the discussion to follow, it is not assumed that there is just one coherent thing one can call the life of Moses or that any sort of teleological meaning(s) it historically had was something above and beyond the literary and theological agendas of the authors

26 That is, assumptions about the nature of deity in the generic sense.

27 Metz, "Meaning of Life," http://plato.stanford.edu/archives/sum2013/entries/lifemeaning/.

28 Gericke, Hebrew Bible, 104.

29 In addition to this, the concept of a soul is itself problematic depending on how it is understood and compared with similar ideas about the human person in ancient Israelite anthropology. For more on this, see James Barr, The Garden of Eden and the Hope of Immortality (London: SCM Press, 1993). 
and redactors of the Pentateuch. ${ }^{30}$ Nor is there the idea that we can know or have to determine what the meaning of Moses' life was for Moses' himself in the sense of assuming there ever was a historical person of the same name. Technically the texts do not offer us the life of Moses in the world behind the text at all. Nor will we ever have a God's eye-view on the matter or even know what the real authors themselves believed. All we have a various perspectives of narrators (as found in the words of the current overt narrator or covertly in those of the various related characters like YHWH, Moses, and others). In the accounts to follow, however, no attempt is made to be exhaustive or even representative. Rather, I shall simply point to some perspectives relevant to the primary anachronistic philosophical concern.

In addition, and irrespective of what was said above, given the theistic framework of the Mosaic narratives (in the world of the text at least), the basic (if in places anachronistic) structure of some or other modern God-based account of the meaning of life relates only vaguely ${ }^{31}$ to some of what is presupposed in the biblical texts. ${ }^{32}$ The general tenet of such a God-based account, if present in the narratives, would be the idea is that YHWH has a plan for the world and that Moses' life was assumed to be meaningful to the degree that he helped YHWH realise this plan, perhaps in the particular way YHWH wanted him to do so. ${ }^{33}$ Fulfilling YHWH's purpose (and doing so freely and intentionally) would then be the sole source of meaning, with the existence of an afterlife not necessary for it. ${ }^{34}$ On this view, then, if Moses failed to do what YHWH intended him to do, then his life was assumed to be meaningless.

Of course, there are many variations of the God-centred view. One of these is the so-called "Purpose theorists" according to whom YHWH's purpose

30 Because the interest of this study lies in a philosophical perspective and due to spatial constraints demanding only immediately relevant and related details, and not because it denies the invaluable contribution of other approaches or the need to incorporate their insights overtly, no standard, critical commentaries on the Pentateuch are cited in the discussion to follow.

31 For more on the vagueness related to the problem, see Allen Lacey, "The Meaning of Life," in The Oxford Companion to Philosophy, ed. Ted Honderich, 2nd ed. (New York: Oxford University Press, 2005), 318-323.

32 Scholarly discussions of the meaning of life in the context of the HB are usually associated with commentaries on Qohelet. Most of these tend to be theological but some comparative philosophy is also present (e.g. Michael Fox comparing Qohelet and Camus). See, however, more recently, Mark Sneed, The Politics of Pessimism: A Social Science Commentary (Atlanta: Society of Biblical Literature, 2012).

33 Metz, "Meaning of Life,” http://plato.stanford.edu/archives/sum2013/entries/lifemeaning/; cf. also Jacob Affolter, "Human Nature as God’s Purpose,” RelS 43 (2007): 443-55.

34 Metz, "Meaning of Life," http://plato.stanford.edu/archives/sum2013/entries/lifemeaning/; cf. also Michael Levine, "What Does Death Have to Do with the Meaning of Life?” RelS 23 (1987): 457-65. 
would somehow confer meaning on Moses' life. Indeed the character of Moses did appear to have derived some sort of meaning in that he fulfilled some of the purposes YHWH assigned to his life, despite failing in others. Yet according to one modern critique of this formulation of the God-based view above, if YHWH did assign Moses a purpose, YHWH would degrade Moses and hence undercut the possibility of Moses obtaining meaning from fulfilling YHWH's purpose. ${ }^{35}$ The latter objection is clearly related to both Kantian ideas of moral autonomy and existentialist notions of authenticity, ${ }^{36}$ yet the strong emphasis on free will is certainly anachronistic. ${ }^{37}$

An alternative God-centred theory would focus less on YHWH as purposive agent and more on the deity as supposedly infinite. ${ }^{38}$ The basic idea is that for a finite condition like Moses' life to be meaningful, it must obtain its meaning from another condition that has meaning. After all,

A regress on meaningful finite conditions is present, and the suggestion is that the regress can terminate only in something infinite, a being so all-encompassing that it need not (indeed, cannot) go beyond itself to obtain meaning from anything else. According to this view, that is God. ${ }^{39}$

So, if Moses' life was assumed to be meaningful, at least according to this view, it might be so in virtue of the sort of work Moses did which presumably obtained its meaning by being related to YHWH's nature. Once again, however, the concept used here is anachronistic in that in many Mosaic narratives YHWH is depicted as a mountain and storm tribal god, that is, a being that does not seem to instantiate the property of being infinite in any meaningful sense of the word. ${ }^{40}$

35 Irving Singer, Creation of Value, 29.

36 Cf. Thaddeus Metz, "Could God's Purpose be the Source of Life's Meaning?” RelS 36 (2000): 297-302; and Dale Jacquette, Six Philosophical Appetizers (Boston: McGraw-Hill, 2001), 20-21.

37 On several occasions in the Mosaic narratives, YHWH seems not to value free will in the same way moderns do. The most familiar example in the text is of a god who "hardens the heart" of a person to do something against their own will, e.g. the Pharaoh (Exod 4:21; 7:3; 9:12; 10:1, 20, 27; 11:10; 14:4, 8, 17, and arguably 14:5, 18) and the Moabite king Sihon (Deut 2:30), etc. One can also ask whether Moses had free will in his being commissioned, given that no attempt to get out of it worked (see below). Or could the Israelites have declined YHWH's offer for making a covenant with them without consequence?

38 Cf. David E. Cooper, "Life and Meaning,” Ratio 18 (2005): 125-37.

39 Metz, "Meaning of Life," http://plato.stanford.edu/archives/sum2013/entries/lifemeaning/.

40 Some Christian philosophers of religion assume that the existence of a god is a necessary condition, e.g. John Cottingham, The Spiritual Dimension: Religion, 
The bottom line with regard to God-centred views on meaning is that their theologies are anachronistic, that is, not identical to those of Mosaic Yahwism(s). At this point then it might do well to ask what the texts themselves assumed regarding the meaning(s) of Moses' life. In the discussion to follow we shall do so from a variety of intra-textual perspectives, namely those of the narrator, the character of YHWH and the character of Moses himself. Of course, these distinctions are somewhat artificial and ultimately unsustainable. Technically everything we have are just the narrators' perspectives, even the words of the characters of YHWH and Moses themselves that are brought to bear on the topic under consideration. Unless this admission and qualification is taken cognisance of, the analyses of the various perspectives on the meanings of Moses' life (narrator, YHWH, and Moses himself) will appear faulty on both textual and contextual grounds. ${ }^{41}$

\section{The Narrator(s') Perspective(s)}

If we look at Moses' life from the perspective of some of the narrator(s), we find that the purpose provided is understandably somewhat fragmented due to source-critical diversity. Reading the life of Moses as an incoherent whole then, we can still say that from this point of view ${ }^{42}$ his life was meaningful to the extent that it contributed to teleological developments in Israelite history. This is hinted at already long before Moses' birth, in Gen 15:12-21 ${ }^{43}$ and to the extent that Moses was the unidentified pawn of prophecy: ${ }^{44}$

As the sun was going down, a deep sleep fell on Abram; and lo, a dread and great darkness fell upon him. Then YHWH said to Abram, "Know of a surety that your descendants will be sojourners in a land

Philosophy and Human Value (Cambridge: Cambridge University Press, 2005); William Lane Craig, "The Absurdity of Life Without God," in Reasonable Faith: Christian Truth and Apologetics, 3rd ed. (Wheaton, IL: Crossway Books, 2008), 6590.

41 Additionally, though the sections 1-3 that form the core of the article to follow contain many quotes, due to spatial limitations incumbent on writing an article it is unfortunately not possible to engage more directly with the material to develop a more nuanced discussion. The standard translations and interpretations of the quoted materials as discussed in mainstream research approaching the data via literary and historical perspectives are assumed to be sufficient for the sake of the argument.

42 In a way, the omniscient narrator's perspective is akin to elements of what the philosopher Thomas Nagel has referred to as a "view from nowhere." See Thomas Nagel, The View from Nowhere (New York: Oxford University Press, 1989). For a philosophical view on the role of stories in the construction of religious meaning, see Don Cupitt, What is a Story? (London: SCM Press, 1991).

43 Translations in this contribution are from the RSV with the divine name replaced by the tetragrammaton.

44 For more on a philosophical assessment of this passage, see Gericke, Hebrew Bible, 393. 
that is not theirs, and will be slaves there, and they will be oppressed for four hundred years; but I will bring judgment on the nation which they serve, and afterward they shall come out with great possessions. As for yourself, you shall go to your fathers in peace; you shall be buried in a good old age. And they shall come back here in the fourth generation; for the iniquity of the Amorites is not yet complete." When the sun had gone down and it was dark, behold, a smoking fire pot and a flaming torch passed between these pieces. On that day YHWH made a covenant with Abram, saying, "To your descendants I give this land, from the river of Egypt to the great river, the river Euphra'tes, the land of the Ken'ites, the Ken'izzites, the Kad'monites, the Hittites, the Per'izzites, the Reph'aim, the Amorites, the Canaanites, the Gir'gashites and the Jeb'usites."

The events described as to transpire in Egypt involve Moses who is not mentioned by name here but who is clearly presupposed. ${ }^{45}$ One might be tempted to say the meaning of Moses' life from this synchronically earlier perspective might be to lead the Israelites to the Promised Land. However, that would not do, not only because Moses is not mentioned (nor is his role as Lawgiver) but given that what he did do in relation to the meaningful events depicted in Gen 15 happened only after he was 80 years old. Surely, the first eight decades of his life were not assumed to be meaningless yet this is what is implied in viewing Moses only as the leader of his people.

On the other hand, perhaps the meaning of life changes over time so that his leadership was the meaning of his life from $80-120$ but not before. ${ }^{46}$ In the narrations of later traditions, Moses' existence does obtain meaning(s) as the lawgiver, leader and prophet it would otherwise lack and which justifies his inclusion in the traditions in the first place. This is the same with regard to authors and redactors of texts in the Pentateuch featuring Moses. Moses' life was assumed to have obtained meaning as a legitimiser of ideology, whether early or late and as an etiological catalyst for Israelite nationalism. According to Deut 34:7-12,

Moses was a hundred and twenty years old when he died; his eye was not dim, nor his natural force abated. And the people of Israel wept for Moses in the plains of Moab thirty days; then the days of

45 Even though Moses is not mentioned, the reference to the divine judgment and leaving with possessions clearly presupposes the events surrounding the character of Moses in the narrative of Exod 7-12.

46 It can always be asked why one should think the meaning of a life is a single overarching theme when it can pertain to certain sections being more meaningful than others and in fact change over time. For more on the meaning of life as complex plurality, see John Kekes, The Human Condition (New York: Oxford University Press, 2010). 
weeping and mourning for Moses were ended. And Joshua the son of Nun was full of the spirit of wisdom, for Moses had laid his hands upon him; so the people of Israel obeyed him, and did as YHWH had commanded Moses. And there has not arisen a prophet since in Israel like Moses, whom YHwH knew face to face, and for all the mighty power and all the great and terrible deeds which Moses wrought in the sight of all Israel.

From this point of view, the frame narration starting in Genesis 15 and ending in Deut 34 seemed to assume that the meaning of Moses' life was to become a prophet who was required to play a key role in the history of Israelite religion in the context of the divine plan for the destiny of the people. ${ }^{47}$ The purpose of Moses' life was to eventually represent YнwH in leading the people. From this perspective, as noted above, the primary locus of meaning is assigned to what was narrated to have transpired in the last 40 years and was not so much bound up with the goals of his mission (leading the people to Canaan) as with the function of his role vis-à-vis YHWH.

In citing Gen 15:12-21 and Deut 34:7-12 above, it might be understood as suggesting that the purpose of Moses' life becomes bifurcated because this function only applies to parts of Moses' life, not the whole, and his role as prophet (YHWH's representative) eclipses the leadership role. By this is not meant that Moses' role as representative conflicts with his leadership role as such. It is only suggested that, seen in this way, whereas Moses' life fulfilled its purpose in revealing YHWH to the people, in the end he had less success in personally leading them in the intended way to the Promised Land as was initially expected from his leadership.

\section{The Character(s') of YHWH's View(s)}

In this section, we ask what Moses' life seemingly meant to the character of YHWH in some of the various sources. ${ }^{48}$ If we take the depictions of YHWH as determining perspectives we might be tempted in assuming that Moses' life had meaning in the worldview of ancient Israelite metaphysics where a god needs a

47 For a reception history of Moses from Exodus onwards, see Jane Beal, Illuminating Moses: A History of Reception from Exodus to the Renaissance, CommSTC (Leiden: Brill, 2013).

48 On the conceptual and philosophical problematic of YHWH as a character in a narrative, see Robert Carroll, Wolf in the Sheepfold: The Bible as Problem for Theology (London: SCM Press, 1997), 37. A more specific introduction to the issues can be found in David Clines, Interested Parties: The Ideology of Writers and Readers of the Hebrew Bible (Sheffield: Sheffield Phoenix Press, 2009). 
people and a mediator/prophet/servant through which he reveals his will and who acts on his behalf. ${ }^{49}$ In Exod 3:4-10 we read:

When YHWH saw that he turned aside to see, God called to him out of the bush, "Moses, Moses!" And he said, "Here am I." Then he said, "Do not come near; put off your shoes from your feet, for the place on which you are standing is holy ground." And he said, "I am the God of your father, the God of Abraham, the God of Isaac, and the God of Jacob.” And Moses hid his face, for he was afraid to look at God. Then YHWH said, "I have seen the affliction of my people who are in Egypt, and have heard their cry because of their taskmasters; I know their sufferings, and I have come down to deliver them out of the hand of the Egyptians, and to bring them up out of that land to a good and broad land, a land flowing with milk and honey, to the place of the Canaanites, the Hittites, the Amorites, the Per'izzites, the Hivites, and the Jeb'usites. And now, behold, the cry of the people of Israel has come to me, and I have seen the oppression with which the Egyptians oppress them. Come, I will send you to Pharaoh that you may bring forth my people, the sons of Israel, out of Egypt.”

In other words, from this point of view Moses' life's meaning was simply to represent YHWH and not saving or leading the people, which, technically, YHWH himself had to do. But in this Moses had little free will as to choose how his life is to unfold. ${ }^{50}$ As commentators have pointed out, a strange mixture of divine foreknowledge and determinism versus ignorance and human freedom exists in the stories of Exod 7-12. On the one hand, it seems that Moses is fated to live out a certain life that is meaningful to YHWH as he becomes an actor on a stage for a play that has already being scripted. And so, according to Exod 7:2-5,

You shall speak all that I command you; and Aaron your brother shall tell Pharaoh to let the people of Israel go out of his land. But I will harden Pharaoh's heart, and though I multiply my signs and wonders in the land of Egypt, Pharaoh will not listen to you; then I will lay my hand upon Egypt and bring forth my hosts, my people the sons of Israel, out of the land of Egypt by great acts of judgment. And the Egyptians shall know that I am YHWH, when I stretch forth my hand upon Egypt and bring out the people of Israel from among them.

49 Thaddeus Metz, “God's Purpose as Irrelevant to Life's Meaning: Reply to Affolter,” RelS 43 (2007): 457-64.

50 For more on the problem of free will in relation to the meaning of life, see John M. Fischer, "Free Will, Death, and Immortality: The Role of Narrative," PhP 34 (2005): 379-403 and John M. Fischer, Our Stories: Essays on Life, Death, and Free Will (New York: Oxford University Press, 2009). 
As noted above, if we say the meaning of Moses life for YHWH was bringing the people out of Egypt the command that he should is complicated metaphysically by the claim that $\mathrm{YHWH}$ himself brings out the people. However, also with regard to Moses' role over and against YHWH's actions a dual causality seems to be operative. Thus, we find the description of YHWH that Moses will act as substitute god, an agent to reveal the glory, power and will of YHWH, thus helping him to keep an age old promise to the patriarchs.

He shall speak for you to the people; and he shall be a mouth for you, and you shall be to him as a god (Exod 4:16).

And YHWH said to Moses, "See, I make you as a god to Pharaoh; and Aaron your brother shall be your prophet” (Exod 7:1).

Working with the idea of Moses qua ersatz deity, what was assumed to be the purpose of this semi-divine existence? Is that not like asking what the purpose of YHWH's own existence might be? But then, Moses was not immortal $^{51}$ and his being designated a "god" adds little to the amount of meaning his life actually has to himself, although it does seem to mean something for YHWH's own status of master versus servant. From the character of YHWH's perspective in this text, the meaning of Moses's life is then indeed to be found in his function for and relation to YHWH primarily and the people secondarily. Here YHWH, Moses and the people form a triad of interconnected channels of meaning, none of which is itself a source or foundation thereof.

But is this all there is to it? Surely Moses life was assumed to have meaning the 40 years he lived in Egypt. Would his life have been meaningless without the Israelites and YHWH as his god? It is hard to see how this would be so. The same goes for the 40 years of married life as a shepherd in Midian. Moses neither knew YHWH nor had any function in relation to him (as is presupposed by a first encounter at the burning bush), yet it hardly makes sense to imagine that he could have been worried that life was meaningless. Since the divine only played a substantial role the last 40 years of his life we can conclude that from the perspective of ancient Israelite metaphysics relating actively to a god is not a sufficient condition for a meaningful life overall.

Of course, since the present discussion is done in the context of a philosophical perspective working with gaps and what is implicit in the text itself, it is important to note that what has been said in this section regarding modality in the metaphysical assumptions behind possible lives Moses' could have lived

51 On the notion of immortality in relation to the problem of the meaning of life, see Thaddeus Metz, “The Immortality Requirement for Life’s Meaning,” Ratio 16 (2003): 161-77; The idea that life can only be meaningful if it is everlasting is not part of the Mosaic narratives' metaphysical assumptions. See also a more philosophical approach in Jeremy J. Wisnewski, “Is the Immortal Life Worth Living?” IJPR 58 (2005): 2736. 
does not deny that in the construction of the narrative such lives are pure speculation and inference. Thus Moses could, at least from a literary-critical perspective, only had one life and every aspect thereof has a legitimating function. First, Moses' disability serves to place the emphasis on written versus oral revelation: Moses' role as writer versus speaker. Second, his life in the Sinai serves to "Israelitise” him, since he had been raised as a prince of Egypt. The discussion of this article does not deny these givens about agendas in the world behind the text demonstrated in other methodologies. It simply chooses to limit the view to a philosophical take on what is presupposed with regard to implicit life-courses within possible worlds in the text, not in terms of explicit life events in the actual one.

\section{The Character(s) of Moses' Perspective(s)}

If we look through at Moses' life through the narrator's characterisations of Moses' own assessments it would seem that his life first had meaning in Egypt by being part of a people. Then in Midian his life seemed to have obtained contingent meaning as a spouse and shepherd, both of which were not assumed to be necessarily connected to relations with YHWH. That Moses' life's meaning was not assumed by him to be dependent on divine purpose is seen in Exod 3-4 where Moses objected to the divine commission no less than five times.

But Moses said to God, "Who am I that I should go to Pharaoh, and bring the sons of Israel out of Egypt?” (Exod 3:11).

Then Moses said to God, "If I come to the people of Israel and say to them, 'The God of your fathers has sent me to you,' and they ask me, 'What is his name?’ what shall I say to them?” (Ex 3:13).

Then Moses answered, "But behold, they will not believe me or listen to my voice, for they will say, 'YHWH did not appear to you.'” (Exod 4:1).

But Moses said to YHWH, "Oh, my Lord, I am not eloquent, either heretofore or since you have spoken to your servant; but I am slow of speech and of tongue" (Exod 4:10).

But he said, “Oh, my Lord, send, I pray, some other person” (Exod $4: 13)$.

Combine this with the way YHWH gets Moses in disfavour with the Israelite people while the deity follows its own time-consuming agenda in and outside Egypt and it would once again seem that YHWH cannot be posited as 
the sole external agent conferring meaning on Moses existence. ${ }^{52}$ In fact, YHWH's purpose for Moses is actually distinguished from Moses' own desires for his life, as when he declines an offer to be the sole heir to YHWH's blessings despite the deity telling him to not resist. In Exod 32:9-14 we read:

And YHWH said to Moses, "I have seen this people, and behold, it is a stiff-necked people; now therefore let me alone, that my wrath may burn hot against them and I may consume them; but of you I will make a great nation.” But Moses besought YHWH his God, and said, "O YHWH, why does your wrath burn hot against your people, whom you have brought forth out of the land of Egypt with great power and with a mighty hand? Why should the Egyptians say, 'With evil intent did he bring them forth, to slay them in the mountains, and to consume them from the face of the earth'? Turn from your fierce wrath, and repent of this evil against your people. Remember Abraham, Isaac, and Israel, your servants, to whom you swore by your own self, and said say to them, 'I will multiply your descendants as the stars of heaven, and all this land that I have promised I will give to your descendants, and they shall inherit it forever." And YHWH repented of the evil which he thought to do to his people.

In fact, the divine commission was an existential burden so that his relationship with YHWH was not a sufficient condition for a meaningful life, ${ }^{53}$ even though during the last 40 years it may have functioned as a necessary one, as is recounted in Num 11:10-15.

Moses heard the people weeping throughout their families, every man at the door of his tent; and the anger of YHWH blazed hotly, and Moses was displeased. Moses said to YHWH, "Why have you dealt ill with your servant? And why have I not found favour in your sight, that you lay the burden of all these people upon me? Did I conceive all these people? Did I bring them forth, that you should say to me, 'Carry them in your bosom, as a nurse carries the sucking child, to the land which you swore to give their fathers?' Where am I to get meat to give to all the people? For they weep before me and say, 'Give us meat, that we may eat.' I am not able to carry all these people alone, the burden is too heavy for me. If you will deal thus with me, kill me at once, if I find favour in your sight, that I may not see my wretchedness.”

52 For more on the burden of leadership in Moses in relation to the meaning of life, see the relevant sections in Robert Davidson, The Courage to Doubt: Exploring an Old Testament Theme (London: SCM Press, 1983).

53 Cf. Metz, “Could God's Purpose?” 293-313. 
This desire not to go on living clearly is possible only if Moses could not find or bear the "purpose" he was presented with. ${ }^{54}$ Moreover, given that his "dream" was taken away from him due to the people's disobedience and an unreasonably harsh sentence for irrational actions, Moses life can even seem as ultimately having been futile. What did he really do that others could not? Who was he really to be significant, besides being chosen?

Of course, from a strictly literary-critical perspective, the passages discussed in this section have very different function and therefore meaning. Exod 3-4 reflects the standard demurring for a prophetic call (a literary convention). In the latter two passages, their rhetorical nature merely indicates the severity of the people's disobedience hyperbolically. Yet all this is acknowledged, but it does not detract from the fact that if one should look at what is implied as to Moses' life and what he at times appears to have wanted from it (even if as part literary convention or rhetoric), the narrator at times seems to hint at the possibility that YHWH and Moses at times had rather different ideas as to what exactly Moses planned for his life and seemed willing to live for.

Even if we look to the meaning of Moses' life from the collective perspective of the Israelites themselves, the fact that he fulfilled the role of one who could lead, mediate, rule and prophesy was not a sufficient condition for meaningfulness either. They not only complained as regards how Moses fulfilled these roles, it is shown in the course of the story that the roles can become redundant, transferred and in fact provoke resentment, frustration and, existentially speaking, aimless wandering. The meaning of Moses' life might at some stages be linked to the survival of his people but his individualism and life-story show that, as with the divine, it can emerge independent therefrom. ${ }^{55}$

\section{F CONCLUSION}

In mainstream discussions of Moses' life, his character is portrayed in the Pentateuch as a stammering, reluctant leader whose main literary function is to legitimate the written revelation, namely, the Torah. Moses' flaws are there so that he does not upstage YHWH. Yet Moses is simultaneously indispensable as the medium of this revelation. In this article, however, though all this is acknowledged, the focus lay elsewhere. A philosophical perspective was opted for which meant looking at the texts from a different angle. The latter was provided by contemporary concerns, concepts and categories constructed in theorising about the meaning of life, in the full knowledge that these are anachronistic, even if not always necessarily distortive.

54 Cf. David Benatar, Better Never to Have Been: The Harm of Coming into Existence (Oxford: Oxford University Press, 2009).

55 Cf. Berit Brogaard and Barry Smith, "On Luck, Responsibility, and the Meaning of Life,” PhP 34 (2005): 443-58. 
It was demonstrated that in the selection of texts presupposing or implying teleological biographical the character Moses' life does not fit the modern existential stereotypes. Moreover, one cannot simply say that Moses' life had just one meaning easily summed up, as is possible in literary-critical perspectives working only with authorial ideological agenda and literary convention. Instead, comparatively-philosophically speaking, Moses' life appears to have had many meanings, in many senses of the word meaning and in some contexts, if we should adopt certain modern religious philosophical standards, no meaning.

Ultimately, not only was there no single meaning, the meaning of Moses' life changed over time and varied according to the role Moses played and the evaluative point of view of the narrator, whether he was looking through his own eyes, those of YHWH, of Moses himself or of the Israelites (or other characters). In the multiplex teleology of the discourse his character shows us changing identities over time and across possible worlds. What we can say is that it is not that Moses' life ever lacked meaning - on the contrary, perhaps it had too many possible meanings, hence the fluidity and pluralist existential anthropology of his character and the desire for dissent implicit in his depictions.

\section{BIBLIOGRAPHY}

Abraham, William J. “The Epistemology of Jesus: An Initial Investigation.” Pages 149-158 in Jesus and Philosophy. Edited by Paul K. Moser. Cambridge: Cambridge University Press, 2009.

Affolter, Jacob. “Human Nature as God’s Purpose.” RelS 43 (2007): 443-55.

Antony, Louise M., ed. Philosophers Without Gods: Meditations on Atheism and the Secular Life. Oxford: Oxford University Press, 2007.

Assmann, Jan. Moses the Egyptian: The Memory of Egypt in Western Monotheism. Cambridge, Harvard University Press, 2009.

Ayer, Alfred-Jules. “The Claims of Philosophy.” Repr. as pages 219-32 in The Meaning of Life. Edited by Elmer D. Klemke. 2nd ed. New York: Oxford University Press, 2000.

Barr, James. The Garden of Eden and the Hope of Immortality. London: SCM Press, 1993.

Beal, Jane. Illuminating Moses: A History of Reception from Exodus to the Renaissance. CommSTC. Leiden: Brill, 2013.

Benatar, David. Better Never to Have Been: The Harm of Coming into Existence. Oxford: Oxford University Press, 2009.

Benatar, David, ed. Life, Death \& Meaning: Key Philosophical Readings on the Big Questions. Lanham, MD: Rowman \& Littlefield Publishers, 2004.

Bernstien, Jay. "Grand Narratives.” Pages 102-23 in Paul Ricoeur: Narrative and Interpretation. Edited by David Wood. London: Routledge, 1991.

Blackburn, Simon. Being Good. New York: Oxford University Press, 2012.

Britt, Brian. Rewriting Moses: The Narrative Eclipse of the Text. JSOTSup 402. GCT 14. London: T \& T Clark, 2004. 
334 Gericke, “The Meaning of Moses’ Life,” OTE 30/2 (2017): 315-336

Brogaard, Berit and Barry Smith. "On Luck, Responsibility, and the Meaning of Life.” Philosophical Papers 34 (2005): 443-58.

Brueggemann, Walter. Theology of the Old Testament: Testimony, Dispute, Advocacy. Minneapolis: Fortress Press, 1997.

Buber, Martin. Moses: The Revelation and the Covenant. New York: Harper, 1958.

Camus, Albert. The Myth of Sisyphus. New York: Vintage Books, 1955.

Carroll, Robert. Wolf in the Sheepfold: The Bible as Problem for Theology. London: SCM Press, 1997.

Chasidah, Yishai. Encyclopaedia of Biblical Personalities: Anthologized from the Talmud, Midrash and Rabbinic Writings. Brooklyn: Shaar Press, 1994.

Clines, David, Interested Parties: The Ideology of Writers and Readers of the Hebrew Bible. Sheffield: Sheffield Phoenix Press, 2009.

Cohen, Joel. Moses: A Memoir. Mahwah, NJ: Paulist Press, 2003.

Cooper, David E. “Life and Meaning.” Ratio 18 (2005): 125-37.

Cottingham, John. On the Meaning of Life. London: Routledge, 2003. . The Spiritual Dimension: Religion, Philosophy and Human Value. Cambridge: Cambridge University Press, 2005.

Craig, William Lane. “The Absurdity of Life Without God.” Pages 65-90 in Reasonable Faith: Christian Truth and Apologetics. 3rd ed. Wheaton, IL: Crossway Books, 2008.

Cupitt, Don. What is a Story? London: SCM Press, 1991.

Davidson, Robert. The Courage to Doubt: Exploring an Old Testament Theme. London: SCM Press, 1983.

Eagleton, Terry. The Meaning of Life: A Very Short Introduction. Oxford: Oxford University Press, 2007.

Fischer, John M. “Free Will, Death, and Immortality: The Role of Narrative.” PhP 34 (2005): 379-403.

. Our Stories: Essays on Life, Death, and Free Will. New York: Oxford University Press, 2009.

Ford, Dennis. The Search for Meaning: A Short History. Berkeley: University of California Press, 2007.

Freud, Sigmund. Moses and Monotheism. New York: Vintage, 1967.

Gericke, Jaco. The Hebrew Bible and Philosophy of Religion. RBL 70. Atlanta, GA. Society of Biblical Literature, 2012.

Goetz, Stewart. The Purpose of Life: A Theistic Perspective. New York: Continuum, 2012.

Houtman, Cornelis. “Moses.” Pages 595-597 in Dictionary of Deities and Demons in the Bible. Edited by Karel van der Toorn, Bob Becking and Pieter Willem van der Horst. Leiden: Brill 1999.

Jacquette, Dale. Six Philosophical Appetizers. Boston: McGraw-Hill, 2001.

James, William. “What Makes a Life Significant?” Pages 49-94 in On Some of Life's Ideals. New York: Henry Holt and Company, 1900.

Kekes, John. The Human Condition. New York: Oxford University Press, 2010.

Kirsch, Jonathan. Moses: A Life. New York: Ballantine, 1998.

Klemke, Elmer D. and Stephen M. Cahn, eds. The Meaning of Life: A Reader. 3rd ed. New York: Oxford University Press, 2007. 
Lacey, Allen. “The Meaning of Life.” Pages 318-323 in The Oxford Companion to Philosophy. Edited by Ted Honderich. 2nd ed. New York: Oxford University Press, 2005.

Levine, Michael. “What Does Death Have to Do with the Meaning of Life?” RelS 23 (1987): 457-65.

Martin, Michael. Atheism, Morality, and Meaning. Amherst, NY: Prometheus Books, 2002.

McEntire, Mark. Struggling with God: An Introduction to the Pentateuch. Macon, GA: Mercer University Press, 2008.

Messerly, John. The Meaning of Life: Religious, Philosophical, Transhumanist and Scientific Approaches. Seattle: Darwin and Hume Publishers, 2012.

Metz, Thaddeus. “Could God's Purpose be the Source of Life's Meaning?” RelS 36 (2000): 297-302;

. "Recent Work on the Meaning of Life.” Ethics 112 (2002): 781-814.

. “The Immortality Requirement for Life’s Meaning.” Ratio 16 (2003): 161-

77.

. “God's Purpose as Irrelevant to Life’s Meaning: Reply to Affolter.” RelS 43 (2007): 457-64.

. "New Developments in the Meaning of Life." Philosophy Compass 2

(2007): 196-217.

. Meaning in Life: An Analytic Study. Oxford: Oxford University Press, 2013.

. "The Meaning of Life." In The Stanford Encyclopedia of Philosophy.

Summer 2007 ed. Edited by Edward N. Zalta. Online: http://plato.stanford.edu /archives/sum2013/entries/life-meaning/

Nagel, Thomas. The View from Nowhere. New York: Oxford University Press, 1989.

Runzo, Joseph and Nancy Martin, eds. The Meaning of Life in the World Religions.

Oxford: Oneworld Publications, 2000.

Sartre, Jean-Paul. Existentialism is a Humanism. Translated by Philip Mairet. London: Methuen \& Co, 1948.

Seachris, Joshua. “The Meaning of Life as Narrative: A New Proposal for Interpreting Philosophy’s ‘Primary’ Question.” Philo 12 (2009): 5-23.

. "Death, Futility, and the Proleptic Power of Narrative Ending." RelS 47

(2011): 141-163.

, ed. Exploring the Meaning of Life: An Anthology and Guide. Oxford:

Wiley-Blackwell, 2012.

. “The Meaning of Life, Analytic Perspectives.” In Internet Encyclopedia of

Philosophy. Online: http://www.iep.utm.edu/mean-ana/.

Sharpe, Robert A. “In Praise of the Meaningless Life.” PhN 25 (1999): 15.

Singer, Irving. Meaning in Life, Volume 1: The Creation of Value. Baltimore: John

Hopkins University Press, 1996.

Sneed, Mark. Ecclesiastes and The Politics of Pessimism: A Social Science

Commentary. Atlanta: Society of Biblical Literature, 2012.

Van Seters, John. The Life of Moses: The Yahwist as Historian in Exodus-Numbers. Louisville: John Knox Press, 1994.

Wiesel, Elie. Messengers of God: Biblical Portraits \& Legends. New York: Random House, 1976.

Wildavsky, Aaron. Moses as Political Leader. Jerusalem: Shalem Press, 2005. 
Wisnewski, Jeremy J. “Is the Immortal Life Worth Living?” IJPR 58 (2005): 27-36.

Wolf, Susan. Meaning in Life and Why It Matters. Princeton: Princeton University Press, 2010.

Prof. Jaco Gericke, North-West University, Vaal Triangle Campus, Faculty of Humanities, Basic Sciences, Theology. Vanderbijlpark. 1900. Email: 21609268@nwu.ac.za. 